\title{
Analisis Tipologi Desa Tertinggal di Kabupaten Bojonegoro
}

\author{
Ulul Albab, Lutfi Muta'ali, Andri Kurniawan
}

Masuk: 29082019 / Diterima: 0910 2019 / Dipublikasi: 31122019

(C) 2019 Fakultas Hukum dan IImu Sosial UNDIKSHA dan IGI

\begin{abstract}
This study aims to analyze the level of village development in Bojonegoro and analyze the spatial pattern of the distribution of underdeveloped villages in Bojonegoro Regency. The type of this research is descriptive survey research with quantitative and qualitative approaches based on primary and secondary data analysis. This study uses factor analysis to determine the level of village development and also determine the factors of level development variations and analysis of village typology to analyze the spatial patterns of the distribution of underdeveloped villages in Bojonegoro Regency. From the results of the study, it can be seen that the level of villages development in Bojonegoro is dominated by developing villages with a percentage of $63.72 \%$ and only $16.05 \%$ of villages with a lagging category. Villages with disadvantaged categories are generally located in hilly areas and around Bengawan Solo. The level of development of the village area in the Bojonegoro Regency is formed by a distance of public facilities factors, natural resource factors, health and poverty factors, disaster mitigation factors, industry, marketing, electricity users factors, and the proportion of schools, the proportion of health workers factors. Underdeveloped villages in Bojonegoro are divided into eight typologies, namely underdeveloped villages in inter-city corridor plains totaling ten villages, backward villages in rural plains totaling 22 villages, backward villages in periphery plains totaling 14 villages, isolated terrain villages only one village, backward villages in Inter-city corridor hills totaled four villages, underdeveloped villages in rural hills totaled 11 villages, and backward villages in isolated hills totaled eight villages. In contrast, the villages in the urban areas are not included in the underdeveloped category.
\end{abstract}

Key words: Level of Development Regions, Village Tipology; Underdeveloped Villages

Abstrak Penelitian ini bertujuan untuk menganalisis tingkat perkembangan desa di Kabupaten Bojonegoro dan menganalisis pola spasial persebaran desa tertinggal di Kabupaten Bojonegoro. Jenis penelitian ini berupa penelitian survei deskriptif dengan pendekatan kuantitatif dan kualitatif yang berbasis pada analisis data primer dan sekunder. Penelitian ini menggunakan analisis faktor untuk menentukan tingkat perkembangan desa serta menentukan penyebab variasi tingkat perkembangan dan analisis tipologi desa untuk menganalisis pola spasial persebaran desa tertinggal di Kabupaten Bojonegoro. Dari hasil penelitian dapat diketahui bahwa tingkat perkembangan wilayah desa-desa di Kabupaten Bojonegoro di dominasi oleh desa dengan kategori berkembang dengan presentase $63,72 \%$ dan hanya $16,05 \%$ desa dengan kategori tertinggal. Desa dengan kategori tertinggal umumnya berada pada daerah perbukitan dan di sekitar Bengawan Solo. Tingkat perkembangan wilayah desa di Kabupaten Bojonegoro dibentuk oleh faktor jarak fasilitas umum, faktor sumberdaya alam, faktor kesehatan dan kemiskinan, faktor mitigasi bencana, faktor industri, pemasaran, pengguna listrik dan faktor proporsi sekolah, proporsi tenaga kesehatan. Desa tertinggal di Bojonegoro dibagi kedalam 8 tipologi, yaitu desa tertinggal di dataran koridor antar kota berjumlah 10 desa, desa tertinggal di dataran perdesaan berjumlah 22 desa, desa tertinggal di dataran pinggiran berjumlah 14 desa, desa tertinggal dataran terisolasi hanya 1 desa, desa tertinggal di perbukitan koridor antar kota berjumlah 4 desa, desa tertinggal di perbukitan perdesaan berjumlah 11 desa, dan desa tertinggal di perbukitan terisolasi berjumlah 8 desa, sedangkan desa di dataran kota tidak tidak ada yang masuk dalam kategori tertinggal.

Kata kunci : Tingkat Perkembangan Wilayah; Tipologi Desa; Desa Tertinggal

\section{Pendahuluan}

Keberagaman kondisi antar daerah

Ulul Albab, Lutfi Muta'ali, Andri Kurniawan

Fakultas Geografi, Universitas Gadjah Mada

ululalbab8080@gmail.com dengan daerah lain mengakibatkan perbedaan kesempatan ekonomi daerah,sehingga pertumbuhan setiap daerah tidak bisa disamakan (Luthfi Muta'ali, 2011). Ketidakmerataan 
pembangunan suatu wilayah ini tidak sejalan dengan tujuan pembangunan nasional yang selain berfokus pada pertumbuhan (growth), juga berfokus pada pemerataan (equity), kesejahteraan (welfare) dan keberlanjutan (sustainability) (Muta'ali, 2014). Williamson (dalam (Muta'ali, 2015) menyatakan bahwa ketimpangan pada tahap awal pembangunan akan semakin membesar dan terkonsentrasi didaerah tertentu. Konsentrasi ketimpangan dapat memunculkan suatu daerah tertinggal yang dapat dibagi menjadi beberapa tipologi. Tipologi dimaksudkan untuk mengenali secara spesifik potensi dan masalah beserta peluang pengembangannya.

Daerah tertinggal pada dasarnya memiliki potensi sumberdaya yang dapat dikembangkan berdasar tipologi wilayahnya. Pemanfaatan sumberdaya secara optimal dapat menstimulus kegiatan perekonomian daerah dan berpeluang menciptakan keunggulan komparatif. Menurut Muta'ali (2015) negara berkembang pada umumnya memiliki keunggulan komparatif pada sektor sumberdaya alam dan bahan baku. Hasil penelitian terhadap pertumbuhan, percepatan pertumbuhan dan kemiskinan di Indonesia antara wilayah yang bertumpu pada sektor pertambangan dan wilayah yang bertumpu pada sektor non pertambangan mengemukakan bahwa pertumbuhan ekonomi pada sektor non pertambangan khususnya pertanian, industri dan jasa dapat mengurangi kemiskinan dan kesenjangan masyarakat. Selain itu pertumbuhan ekonomi pada sektor pertanian, industri dan jasa memicu pertumbuhan ekonomi berkelanjutan serta dapat mengurangi kemiskinan dan kesenjangan yang ada di wilayahnya. Sedangkan pertumbuhan ekonomi yang terjadi di sektor pertambangan menimbulkan kesenjangan dan kemiskinan masyarakat di wilayahnya (Bhattacharyya \& Resosudarmo, 2014).

Selain pertumbuhan ekonomi, pemerataan sebagai implementasi tujuan pembangunan nasioanal juga harus dapat terealisasikan agar jurang pemisah antar daerah maju dan tertinggal dapat di minimalkan. Perihal implementasi pemerataan di Indonesia masih memiliki beberapa tantangan terutama tantangan dari aspek fisik atau geografisnya, tidak terkecuali pada tiap-tiap kabupaten/kota di Indonesia yang seringkali hanya berfokus pada pertumbuhan ekonomi tetapi ketimpangan antar wilayah dikabupatennya cukup tinggi dikarenakan kondisi fisik atau geografisnya.

Sejarah kemiskinan di Bojonegoro sudah terjadi sangat lama, bahkan sejak jaman kolonialisme Belanda. Berdasar data BPS pada tahun 2008 kondisi jalan di Bojonegoro $80 \%$ rusak, tingkat kemiskinan $18,78 \%$ serta masih rendahnya tingkat kepercayaan masyarakat kepada pemerintah dan pengelolaan bencana belum maksimal. Meski berlimpah sumberdaya alam, masyarakat Bojonegoro masih mengalami kemiskinan hingga pada tahun 2007 Bojonegoro menempati daerah termiskin ketiga di Jawa Timur (BPS, 2007). Panders (1984) mengatakan bahwa kemiskinan Bojonegoro sudah sangat mewabah. Tanah yang gersang dan sulit ditanami tumbuhan, tanaman dibantaran Bengawan Solo yang sering diterjang banjir. Panders menambahkan penyebab kemiskinan di Bojonegoro antara lain minimnya irigasi, diskriminasi pendidikan serta hutang kepada rentenir. Namun sekarang kondisi Bojonegoro berangsur-angsur membaik hingga tahun 2016 Bojonegoro berhasil keluar dari 10 besar daerah termiskin di Jawa Timur.

Sugiyarto, Mulyo, \& Seleky (2015) menyatakan bahwa angka kemiskinan rumah tangga di Bojonegoro sekitar 15\% jika mengacu kriteria dari BPS, sedangkan 
lebih dari $40 \%$ rumah tangga yang tergolong miskin jika mengacu kriteria dari ADB dan Bank Dunia. BPS menyatakan bahwa tahun 2016 angka kemiskinan di Bojonegoro turun dari $15,71 \%$ menjadi $14,60 \%$. Meskipun angka kemiskinan menurun, tetapi untuk indeks kedalaman dan keparahan kemiskinan justru mengalami peningkatan. Indeks kedalaman kemiskinan dari 2,01\% menjadi $2,41 \%$ di tahin 2016. Indeks keparahan kemiskinan dari $0,42 \%$ menjadi $0,54 \%$ diyahun 2016. Hal ini mengindikasikan bahwa mayoritas masyarakat miskin level bawah justru semakin menjauh dibawah garis kemiskinan serta realita ketimpangan semakin jelas adanya.

Secara geografis, Bojonegoro dilalui oleh Bengawan Solo mengalir dari selatan, kemudian mengalir ke arah timur disepanjang wilayah utara Bojonegoro melewati 15 kecamatan. Bagian utara merupakan Daerah Aliran Sungai Bengawan Solo yang cukup subur dengan pertanian yang ekstensif. Bagian selatan adalah pegunungan kapur yang merupakan rangkaian Pegunungan Kendeng. Bagian barat laut adalah bagian dari rangkaian Pegunungan Kapur Utara. Daerah Bojonegoro merupakan daerah yang minim kegiatan vulkanik sehingga jarang sekali ditemui batuan beku. Umumnya daerah Bojonegoro merupakan dataran rendah yang yang dianugerahi aliran Sungai Bengawan Solo sebagai seumber irigasi pertanian.

Menjadikan Bojonegoro sebagai sumber ekonomi kerakyatan, dan sosial budaya lokal untuk terwujudnya masyarakat yang beriman, sejahtera dan berdaya saing merupakan visi dan misi yang diusung Bojonegoro sebagai dasar pembangunan wilayahnya. Terdapat prinsip kerakyatan dalam pemanfaatan sumberdaya Bojonegoro untuk kesejahteraan masyarakat. Demi terwujudnya kesejahteraan tersebut, ketimpangan Bojonegoro harus diminimalkan sesegera mungkin, baik ketimpangan pembangunan ataupun ekonomi agar kesejahteraan masyarakat dapat tercapai.

Penelitian mengenai pengembangan wilayah tertinggal sudah pernah dilakukan oleh beberapa orang terdahulu. Penelitian-penelitian tersebut dilakukan di beberapa lokasi dengan metode, pendekatan dan unit analisis yang berbeda-beda. Unit analisis yang pernah dikaji oleh beberapa peneliti terdahulu yaitu kecamatan dan kabupaten seperti penelitian mengenai ketimpangan perkembangan wilayah yang dilakukan oleh Ardiyanto (2018) untuk menganalisis tipologi wilayah di Kota Palembang dan menganalisis faktor-faktor penentu dalam permasalahan ketimpangan di Kota Palembang. Perbedaan penelitian Ardiyanto (2018) dengan penelitian ini terletak pada variabel-variabel yang digunakan untuk mengukur disparitas pada penelitiannya adalah indikator ekonomi berupa Indeks Ekonomi tiap kelurahan sedangkan dalam penelitian ini variabel yang digunakan adalah letak geografis, sumberdaya alam, sumberdaya manusia, prasarana dan sarana serta kerawanan bencana alam. Perbedaan selanjutnya terletak pada pembagian tipologi, Ardiyanto (2018) hanya membagi berdasar aspek fisik sedangkan dalam penelitian ini selain memperhatikan aspek fisik namun juga memperhatikan aspek menuju pusat pertumbuhan.

Selanjutnya Chen \& Ge (2015) melakukan penelitian mengenai analisis titik pola spasial pada desa miskin di Cina. Desa-desa tertinggal di dapat dari data pemerintah Cina pada tahun 2011. Desadesa tertinggal tersebut dianalisis dengan Fungsi K Ripley dan Rasio Tetangga terdekat untuk mengetahui karakteristik pada tiap pola spasial desa tertinggal selanjutnya menganalisis hubungan tiap pola dengan faktor alam, sosial, dan 
hubungan tetangga antar desa. Perbedaan penelitian Chen dan Ge (2015) dengan penelitian ini adalah pembagian pola spasialnya, dalam penelitian ini pola spasial dibagi dengan aspek yang lebih spesifik yaitu aspek fisik fisik dan jarak menuju pusat pertumbuhan sedangkan penelitian Chen \& Ge (2015) lebih menekankan pada bentuk pola spasial desa tertinggal apakah mengelompok atau menyebar saja.

Berdasarkan pemaparan tersebut, penulis juga merasa perlu untuk mengidentifikasi tingkat perkembangan desa dan faktor penyebab adanya variasi tingkat perkembangan desa di Kabupaten Bojonegoro. Selanjutnya menganalisis pola spasial persebaran desa tertinggal berdasarkan keterkaitan kondisi lingkungan fisik serta posisi geografis terhadap pusat pertumbuhan.

\section{Metode}

Jenis penelitian ini berupa penelitian survei deskriptif dengan pendekatan kuantitatif dan kualitatif yang berbasis pada analisis data primer dan sekunder.

Tingkat perkembangan wilayah desa dihitung dengan memperhatikan beberapa variabel yaitu :

1. Letak Geografis

1) Jarak desa ke pusat kecamatan.

2) Jarak menuju fasilitas kesehatan

3) Jarak menuju fasilitas pendidikan

4) Jarak menuju fasilitas ekonomi

2. Sumberdaya Alam

1) Luas sawah

2) Jumlah ternak

3) Jumlah industri

3. Sumberdaya Manusia

1) Proporsi penduduk dengan gizi buruk dan cacat

2) Proporsi tenaga kesehatan

3) Proporsi sd, smp dan sma

4) Proporsi penduduk miskin

4. Prasarana dan Infrastruktur

1) Jumlah fasilitas ekonomi
2) Jumlah fasilitas kesehatan

3) Proporsi pengguna listrik

4) Jumlah operator telepon seluler

5. Kerawanan bencana alam

1) Jumlah kejadian bencana alam

Pola spasial persebaran desa tertinggal di Kabupaten Bojonegoro dengan memperhatikan beberapa variabel yaitu :

1. Tingkat perkembangan wilayah desa

1) Jumlah desa tertinggal

2. Kondisi fisik

1) Perbukitan

2) Dataran

3. Kondisi posisi geografis terhadap pusat pertumbuhan

1) Desa di kota

2) Desa di pinggiran kota

3) Desa di koridor antar kota

4) Desa di perdesaan

5) Desa yang terisolasi

Metode analisis faktor dapat digunakan untuk mengelompokkan wilayah berdasar karakteristik utama suatu kasus studi dengan sejumlah variabel yang besar (multivariabel). Analisis faktor mampu mereduksi sejumlah variabel menjadi beberapa faktor yang jumlahnya lebih kecil dari variabel keseluruhan yang digunakan tetapi memiliki informasi yang hampir sama serta dapat melihat indikatorindikator mana yang dominan.

Variabel tingkat perkembangan wilayah tersebut diolah menggunakan analisis faktor. Analisis faktor bertujuan untuk menemukan hubungan antar beberapa variabel yang saling independen satu dengan yang lainnya sehingga dapat dikelompokkan menjadi satu atau beberapa kumpulan variabel yang disebut faktor, faktor tersebut adalah ringkasan dari beberapa variabel awal. Analisis faktor juga digunakan untuk mengetahui klasifikasi desa-desa di Kabupaten Bojonegoro serta dapat diketahui besaran pengaruh masing-masing faktor dalam 
variasi tingkat perkembangan wilayah desa-desa di Kabupaten Bojonegoro.

Analisis Tipologi Desa

Analisis tipologi desa dalam penelitian ini merupakan analisis pengelompokan desa-desa tertinggal ditinjau dari aspek spasial yaitu berdasar lingkungan fisik dan jarak desa tertinggal tersebut menuju pusat pertumbuhannya. Berdasarkan Peraturan Menteri Dalam Negeri Nomor 12 Tahun 2007 Tentang Pedoman Penyusunan dan Pendayagunaan Data Profil Desa dan Kelurahan menjelaskan bahwa Tipologi Desa merupakan suatu kondisi yang spesifik dari keunggulan potensi sumberdaya alam, sumberdaya manusia, potensi kelembagaan serta potensi saranana prasarana dalam menentukan arah pengembangan dan pembinaan masyarakat. Potensi-potensi tersebut dapat dikelompokkan berdasarkan karakteristik yang sama antar wilayah kedalam satu tipologi wilayah yang sama. Pengelompokan tersebut berdasar atas kesamaan ciri-ciri wilayah dan masyarakatnya untuk mencapai tujuan tertentu.

Pengelompokan dalam penelitian ini berdasar aspek fisik seperti desa pegunungan, perbukitan, dataran, pesisir/pantai, dan pulau kecil serta berdasar aspek posisi geografis terhadap pusat pertumbuhan seperti desa di kota (urban), desa di pinggiran kota, desa di koridor antar kota, desa di perdesaan, dan desa terisolasi.

\section{Hasil dan Pembahasan}

\section{Tingkat Perkembangan Wilayah Desa- Desa di Kabupaten Bojonegoro}

Data-data variabel dalam penelitian ini didapat dari data potensi desa yang dikeluarkan BPS tahun 2018 dan kecamatan dalam angka tahun 2018. Variabel yang dianggap layak adalah variabel dianggap mewakili seluruh variabel yang digunakan. Variabel yang kurang layak akan dikeluarkan dari analisis dan dilakukan pengujian ulang hingga semua variabel yang diuji dianggap layak.

Berdasarkan hasil analisis faktor dengan menggunakan 5 variabel (16 indikator) sebagai variabel penentu tingkat perkembangan wilayah. Tahap awal dihasilkan output KMO and Barlett's Test yang menggambarkan angka signifikansi dari variabel-variabel yang diuji.

Tabel 1. Tabel KMO and Barlett's Test

untuk Kelayakan Variabel Tingkat Perkembangan Wilayah

\begin{tabular}{lll}
\hline \multicolumn{2}{l}{ Kaiser-Meyer-Olkin Measure of Sampling Adequacy. } & $\mathbf{0 , 6 0 3}$ \\
\hline Bartlett's & Approx. Chi-Square & 398,034 \\
Test of & Df & 120 \\
Sphericity & Sig. & 0,000 \\
\hline
\end{tabular}

Sumber: Analisis Data Primer, 2019

Berdasarkan Tabel 1 didapatkan angka KMO and Barlett's Test sebesar $0,603(>0,5)$ serta signifikansi 0,000 yang jauh di bawah 0,05 yang berarti variabel dan jumlah data yang digunakan sudah dapat dianalisis lebih lanjut. Output berikutnya yang dianalisis adalah Antiimage Matrics, khususnya pada bagian anti image correlation. Pada anti image correlation, angka korelasi ditandai dengan simbol "a" yang berderet secara diagonal dari kiri atas hingga kanan bawah. Variabel dengan nilai korelasi $<0,5$ akan dikeluarkan dari analisis faktor dan dilakukan pengujian ulang. Pada uji yang pertama, output anti image correlation seluruh variabel memiliki nilai korelasi $>0,5$, hal itu menunjukkan bahwa semua variabel saling berkorelasi dan akan mempunyai kecenderungan untuk 
mengelompok serta membentuk faktor tertentu.

Setelah output anti image correlation dilanjutkan dengan output Total Variance Explained yang bertujuan untuk mengetahui informasi terkait faktor penyebab variasi tingkat perkembangan yang akan terbentuk. Hal yang menjadi perhatian dalam Total Variance Explained adalah asumsi dasar dalam angka eigenvalues, di mana angka yang digunakan adalah angka faktor diatas 1, sedangkan angka faktor yang di bawah 1 tidak digunakan untuk menghitung faktor yang terbentuk. Angka eigenvalues dalam output Total Variance Explained menunjukkan bahwa ada 6 faktor utama yang mampu menjelaskan variasi tingkat perkembangan wilayah dalam penelitian ini. Enam faktor tersebut didasarkan pada angka eigenvalues yang nilainya diatas 1 . Keseluruhan variabel dalam penelitian ini diringkas menjadi 6 faktor dengan besaran initial eigenvalues secara cumulative adalah $51,627 \%$ yang artinya 6 faktor tersebut mampu menjelaskan 51,627\% penyebab terjadinya variasi tingkat perkembangan wilayah di Kabupaten Bojonegoro. Jadi dalam penelitian ini, variabel-variabel yang digunakan kurang merepresentasikan penyebab terjadinya variasi tingkat perkembangan wilayah di Kabupaten Bojonegoro karena mayoritas variabel yang digunakan adalah variabel yang berhubungan dengan variabel penyebab variasi tingkat perkembangan wilayah yang berasal dari dalam (internal) desa-desa tersebut seperti variabel letak geografis, sumberdaya alam, sumberdaya manusia, sarana dan prasaran serta kerawanan bencana alam. Sedangkan untuk faktor dari luar (eksternal) seperti faktor historis, politis, kebijakan, dan administratif kemungkinan besar cukup berpengaruh juga untuk menjadi penyebab terjadinya variasi tingkat perkembangan wilayah di Kabupaten Bojonegoro. Untuk lebih jelasnya mengenai data pada Total Variance Explained, seperti terlihat pada Tabel 2.

Tabel 2. Total Variance Explained

\begin{tabular}{ccccccc}
\hline \multirow{2}{*}{ Component } & \multicolumn{3}{c}{ Initial Eigenvalues } & \multicolumn{3}{c}{ Rotation Sums of Squared Loadings } \\
\cline { 2 - 6 } & Total & Total & $\begin{array}{c}\text { \% of } \\
\text { Variance }\end{array}$ & $\begin{array}{c}\text { Cumulative } \\
\%\end{array}$ & $\begin{array}{c}\text { \% of } \\
\text { Variance }\end{array}$ & $\begin{array}{c}\text { Cumulative } \\
\%\end{array}$ \\
\hline 1 & 1,972 & 1,562 & $\mathbf{9 , 7 6 1}$ & 9,761 & 12,324 & 12,324 \\
2 & 1,607 & 1,512 & $\mathbf{9 , 4 5 1}$ & 19,212 & 10,047 & 22,370 \\
3 & 1,342 & 1,430 & $\mathbf{8 , 9 3 5}$ & 28,147 & 8,387 & 30,757 \\
4 & 1,182 & 1,414 & $\mathbf{8 , 8 4 0}$ & 36,987 & 7,390 & 38,147 \\
5 & 1,097 & 1,184 & $\mathbf{7 , 4 0 0}$ & 44,387 & 6,859 & 45,006 \\
6 & 1,059 & 1,158 & $\mathbf{7 , 2 4 0}$ & 51,627 & 6,621 & $\mathbf{5 1 , 6 2 7}$ \\
7 & 0,984 & & & & 6,150 & 57,777 \\
8 & 0,933 & & & & 5,834 & 63,611 \\
9 & 0,913 & & & & 5,704 & 69,315 \\
10 & 0,814 & & & & 5,091 & 74,406 \\
11 & 0,801 & & & & 5,003 & 79,409 \\
12 & 0,742 & & & & 4,636 & 84,045 \\
13 & 0,691 & & & & 4,316 & 88,362 \\
14 & 0,656 & & & & 4,103 & 92,464 \\
15 & 0,624 & & & & 3,898 & 96,362 \\
\hline
\end{tabular}

Sumber: Analisis Data Primer, 2019

Analisis faktor dapat menghasilkan nilai skor faktor yang digunakan untuk menyusun indeks komposit dengan cara mencari total score tiap desa yang didapat melalui rumus \% of Variance dikalikan dengan nilai faktor 1 hingga 6 sehingga di 
dapat persamaan total skor desa $\mathrm{x}=$ $(9,761 \times$ nilai skor faktor 1$)+(9,451 \times$ nilai skor faktor 2$)+(8,935 \times$ nilai skor faktor 3$)$ $+(8,840 \times$ nilai skor faktor 4$)+(7,400 \times$ nilai skor faktor 5$)+(7,240 \times$ nilai skor faktor 6 ). Nilai \% variance yang digunakan adalah nilai varian yang terdapat pada kolom Rotation Sums of Squared Loadings di tabel Total Variance Explained. Kemudian dari total skor tersebut diklasifikan menjadi desa tertinggal, berkembang dan maju dengan cara menghitung interval di tiap-tiap kelas. Penelitian ini menggunakan perhitungan $>r+s d$ untuk menentukan kelas maju, $(\mathrm{r}+\mathrm{sd})$ sampai $(<\mathrm{r}-\mathrm{sd})$ untuk kelas berkembang dan $<r$-sd untuk kelas tertinggal sesuai dengan keadaan persebaran data dalam perhitungan tingkat perkembangan wilayah tiap desa serta supaya proporsi tiap kelas intervalnya rasional.

Berdasarkan perhitungan maka di perolehan interval di tiap-tiap kelas yaitu 1) untuk kelas maju, merupakan desa dengan skor tingkat perkembangan wilayah > $21,505,2)$ untuk kelas berkembang, merupakan desa dengan skor tingkat perkembangan wilayah antara 21,504 hingga -8,5450, dan 3) untuk kelas tertinggal, merupakan desa dengan skor tingkat perkembangan wilayah < 8,5451Lebih jelas mengenai tingkat perkembangan wilayah desa-desa di Kabupaten Bojonegoro seperti terlihat pada Tabel 3 dan Gambar 1.

Tabel 3. Tingkat Perkembangan Wilayah Desa di Kabupaten Bojonegoro

\begin{tabular}{|c|c|c|c|c|c|c|c|}
\hline \multirow[b]{2}{*}{ Kecamatan } & \multicolumn{6}{|c|}{ Tingkat Perkembangan Wilayah } & \multirow[b]{2}{*}{ Jumlah } \\
\hline & $\begin{array}{c}\text { Maju } \\
\text { (Desa) }\end{array}$ & $\%$ & $\begin{array}{c}\text { Berkembang } \\
\text { (Desa) }\end{array}$ & $\%$ & $\begin{array}{l}\text { Tertinggal } \\
\text { (Desa) }\end{array}$ & $\%$ & \\
\hline Margomulyo & 1 & 16,7 & 2 & 33,3 & 3 & 50,0 & 6 \\
\hline Ngraho & 0 & 0,0 & 15 & 93,8 & 1 & 6,3 & 16 \\
\hline Tambakrejo & 4 & 22,2 & 11 & 61,1 & 3 & 16,7 & 18 \\
\hline Ngambon & 0 & 0,0 & 3 & 60,0 & 2 & 40,0 & 5 \\
\hline Sekar & 0 & 0,0 & 1 & 16,7 & 5 & 83,3 & 6 \\
\hline Bubulan & 0 & 0,0 & 5 & 100,0 & 0 & 0,0 & 5 \\
\hline Gondang & 0 & 0,0 & 2 & 28,6 & 5 & 71,4 & 7 \\
\hline Temayang & 2 & 16,7 & 5 & 41,7 & 5 & 41,7 & 12 \\
\hline Sugihwaras & 6 & 35,3 & 10 & 58,8 & 1 & 5,9 & 17 \\
\hline Kedungadem & 9 & 39,1 & 12 & 52,2 & 2 & 8,7 & 23 \\
\hline Kepohbaru & 5 & 20,0 & 19 & 76,0 & 1 & 4,0 & 25 \\
\hline Baureno & 8 & 32,0 & 15 & 60,0 & 2 & 8,0 & 25 \\
\hline Kanor & 5 & 20,0 & 14 & 56,0 & 6 & 24,0 & 25 \\
\hline Sumberejo & 7 & 26,9 & 18 & 69,2 & 1 & 3,8 & 26 \\
\hline Balen & 5 & 21,7 & 16 & 69,6 & 2 & 8,7 & 23 \\
\hline Sukosewu & 4 & 28,6 & 8 & 57,1 & 2 & 14,3 & 14 \\
\hline Kapas & 3 & 14,3 & 15 & 71,4 & 3 & 14,3 & 21 \\
\hline Bojonegoro & 5 & 27,8 & 13 & 72,2 & 0 & 0,0 & 18 \\
\hline Trucuk & 1 & 8,3 & 8 & 66,7 & 3 & 25,0 & 12 \\
\hline Dander & 5 & 31,3 & 10 & 62,5 & 1 & 6,3 & 16 \\
\hline Ngasem & 2 & 11,8 & 15 & 88,2 & 0 & 0,0 & 17 \\
\hline Gayam & 2 & 16,7 & 8 & 66,7 & 2 & 16,7 & 12 \\
\hline Kalitidu & 3 & 16,7 & 14 & 77,8 & 1 & 5,6 & 18 \\
\hline Malo & 0 & 0,0 & 12 & 60,0 & 8 & 40,0 & 20 \\
\hline Purwosari & 2 & 16,7 & 4 & 33,3 & 6 & 50,0 & 12 \\
\hline Padangan & 3 & 18,8 & 12 & 75,0 & 1 & 6,3 & 16 \\
\hline Kasiman & 5 & 50,0 & 5 & 50,0 & 0 & 0,0 & 10 \\
\hline Kedewan & 0 & 0,0 & 2 & 40,0 & 3 & 60,0 & 5 \\
\hline Jumlah & 87 & 20,23 & 274 & 63,72 & 69 & 16,05 & 430 \\
\hline
\end{tabular}

Sumber: Analisis Data Primer, 2019 


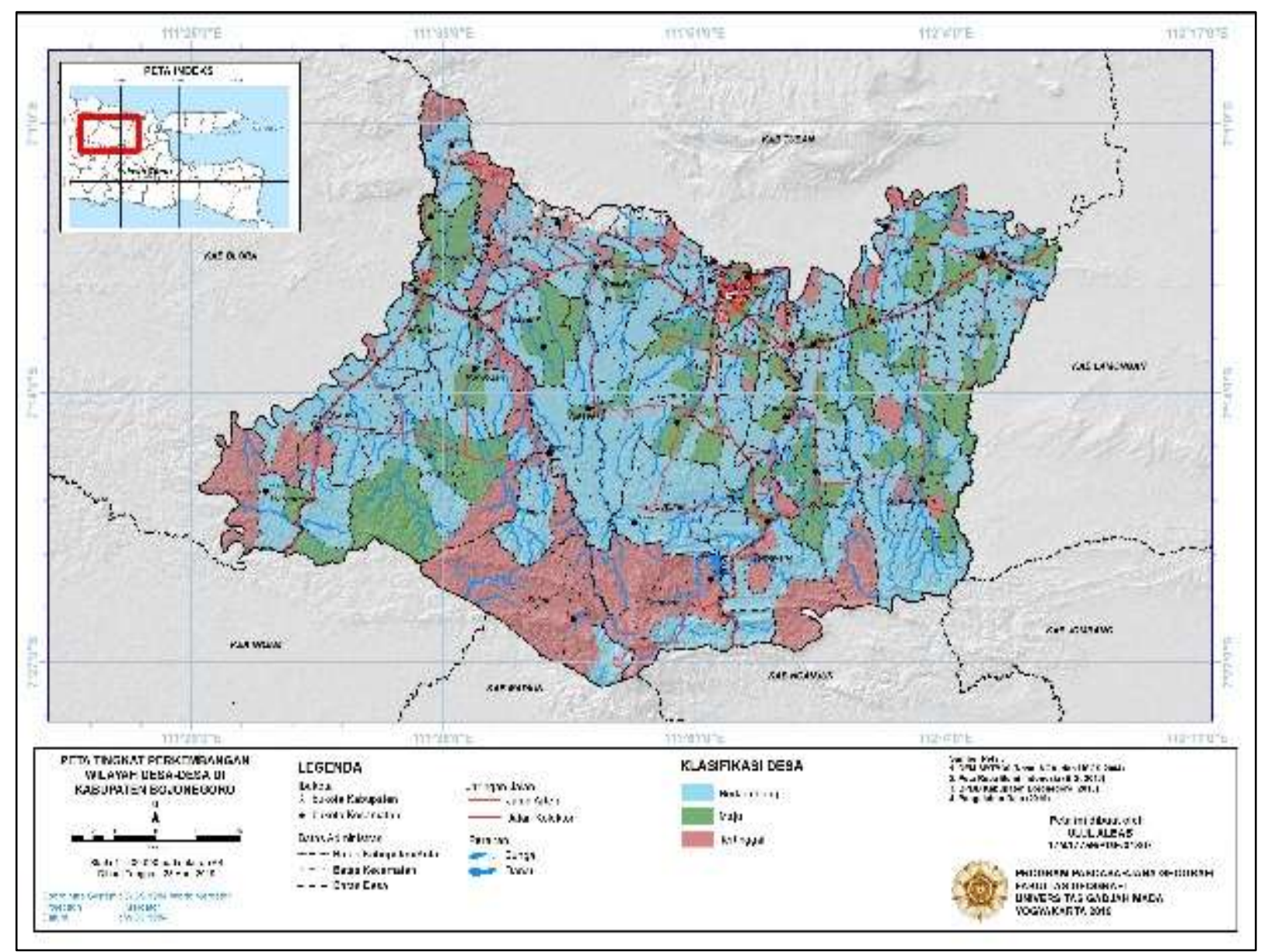

Gambar 1. Peta Tingkat Perkembangan Wilayah Desa di Kabupaten Bojonegoro

Gambar 1 menunjukkan tingkat perkembangan wilayah setiap desa di Kabupaten Bojonegoro. Terdapat beberapa kecamatan yang memiliki jumlah desa tertinggal lebih dari $50 \%$ seperti Kecamatan Margomulyo dengan $50 \%$ desanya masuk kategori tertinggal, Kecamatan Sekar 83\%, Kecamatan Gondang $71,4 \%$, Kecamatan Purwosari $50 \%$, dan Kecamatan Kedewan 60\%. Mayoritas kecamatan dengan jumlah desa tertinggal diatas $50 \%$ adalah Kecamatan yang daerahnya berupa perbukitan dan hanya Kecamatan Purwosari yang berada didaerah dataran. Hal ini menggambarkan bahwa kondisi geografis berupa perbukitan kapur berdampak pada tingkat perkembangan wilayah suatu daerah. Daerah perbukitan menyajikan bentang lahan yang bergelombang sehingga menyulitkan akses menuju daerah tersebut, ditambah lagi jika kualitas jalan yang ada cukup buruk. Selain terkonsentrasi di wilayah perbukitan, desa-desa tertinggal juga menyebar di sekitar aliran Bengawan Solo yang melintas dari sisi timur menuju sisi utara Kabupaten Bojonegoro.

Desa kategori maju banyak berada di daerah Kabupaten Bojonegoro tengah dengan relief yang cukup landai. Desa dengan kategori tertinggal banyak berada pada daerah dengan relief berbukit seperti daerah di sebelah barat laut dan selatan Kabupaten Bojonegoro yang merupakan daerah bukit kapur. Desa dengan kategori berkembang tersebar merata di seluruh Kabupaten Bojonegoro dengan jumlah 274 desa atau 63,72\% desa di Kabupaten Bojonegoro berstatus 
berkembang menurut perhitungan peneliti.

Presentase desa tertinggal di Kabupaten Bojonegoro terbilang rendah yaitu 16,05\%. Angka tersebut lebih kecil daripada presentase desa maju sebesar $20,23 \%$ sedangkan presentase terbanyak adalah desa-desa yang masuk dalam kategori berkembang sebesar $63,72 \%$. Hal ini menunjukkan bahwa Kabupaten Bojonegoro saat ini sedang bangkit untuk mengentaskan desa-desa tertinggal di wilayahnya sehingga banyak desa yang masuk dalam kategori berkembang. Banyaknya desa berkembang ini juga didukung oleh pembangunan sarana dan prasarana demi menunjang kehidupan warga di Kabupaten Bojonegoro.

Desa dengan kategori tertinggal umumnya memiliki fasilitas yang sangat terbatas, yang artinya tidak semua fasilitas dasar tersedia di desa tersebut. Selain keterbatasan fasilitas, aksesibilitas menuju desa tertinggal juga kurang memadai seperti kondisi jalan yang masih berupa tanah dan sempit serta minim penerangan. Kondisi yang serba terbatas tersebut disebabkan letak desa tersebut yang umumnya cukup jauh dari pusat-pusat kegiatan seperti desa-desa di Kecamatan Sekar dan Gondang yang berbatasan dengan Kabupaten Madiun dan Nganjuk sehingga daerah-daerah tersebut kurang mendapat perhatian. Medan yang sulit juga menjadi penyebab lain ketertinggalan suatu desa.

Desa kategori maju umumnya merupakan desa yang letaknya dekat dengan jalan arteri yang menghubungkan Blora - Bojonegoro Lamongan namun tidak semua desa di jalan arteri masuk dalam kategori maju seperti Desa Geneng dan Desa Tebon yang berada pada jalur arteri penghubung Ngawi dan Bojonegoro. Di sekitar jalan arteri Ngawi - Bojonegoro masih didominasi dengan hutan khususnya hutan jati dan kondisi lingkungan berbukit. Area yang mayoritas adalah hutan merupakan salah satu faktor penghambat perkembangan desa-desa tersebut. Hal yang sama terjadi juga pada Desa Kedungsari yang berada pada jalan arteri Nganjuk - Bojonegoro juga mengalami ketertinggalan berdasarkan perhitungan peneliti. Selain di sepanjang jalan arteri, desa tertinggal juga cukup banyak ditemukan di daerah sebelah utara Bengawan Solo.

Desa dengan kategori maju sering kali merupakan pusat kegiatan ataupun letaknya berdekatan dengan pusat kota dan pusat kegiatan seperti kegiatan sosial serta ekonomi pada Pusat Kegiatan Lokal (PKL) dan Pusat Pelayanan Kawasan (PPK) yang tertera dalam dokumen RTRW Kabupaten Bojonegoro Pasal 7. Ada juga beberapa desa yang masuk dalam kategori maju karena berdekatan dengan wilayah pertambangan minyak bumi sehingga secara fasilitas, wilayah tersebut cukup lengkap seperti Desa Gayam.

Selain dapat digunakan untuk menentukan tingkat perkembangan wilayah, analisis faktor juga dapat digunakan untuk menentukan penyebab terjadinya variasi tingkat perkembangan wilayah. Faktor penyebab tersebut dapat dilihat pada tabel Rotated Component Matrix. Component yang bernilai $>0,5$ dan $>-0,5$ digunakan untuk menentukan faktor penyebab terjadinya variasi tingkat perkembangan wilayah. Untuk lebih jelasnya mengenai tabel Rotated Component Matrix dapat dilihat pada Tabel 4. 
Tabel 4. Rotated Component Matrix

\begin{tabular}{ccccccc}
\hline \multirow{2}{*}{ Indikator } & $\mathbf{7}$ & \multicolumn{7}{c}{ Component } \\
\cline { 2 - 7 } & $\mathbf{1}$ & $\mathbf{2}$ & $\mathbf{3}$ & $\mathbf{4}$ & $\mathbf{5}$ & $\mathbf{6}$ \\
\hline I & $\mathbf{0 , 6 9 7}$ & $-0,004$ & $-0,043$ & 0,035 & $-0,041$ & 0,035 \\
II & $\mathbf{0 , 6 0 2}$ & 0,018 & 0,106 & 0,261 & $-0,040$ & $-0,026$ \\
III & $\mathbf{0 , 5 7 8}$ & $-0,017$ & 0,015 & $-0,075$ & 0,065 & $-0,093$ \\
IV & 0,014 & $\mathbf{0 , 7 3 6}$ & 0,058 & 0,087 & 0,157 & 0,083 \\
V & 0,089 & $\mathbf{0 , 5 4 4}$ & 0,025 & 0,252 & 0,010 & 0,083 \\
VI & 0,173 & $\mathbf{- 0 , 5 4 4}$ & 0,203 & 0,343 & 0,148 & 0,124 \\
VII & $-0,297$ & 0,016 & $\mathbf{0 , 6 2 3}$ & 0,031 & 0,021 & $-0,089$ \\
VIII & 0,258 & $-0,308$ & $\mathbf{0 , 6 1 5}$ & 0,093 & $-0,081$ & 0,008 \\
IX & 0,282 & 0,208 & $\mathbf{0 , 5 2 6}$ & $-0,085$ & 0,236 & 0,111 \\
X & 0,104 & 0,101 & $-0,102$ & $\mathbf{0 , 7 3 2}$ & 0,028 & $-0,206$ \\
XI & $-0,008$ & 0,071 & 0,094 & $\mathbf{0 , 7 1 7}$ & $-0,052$ & 0,178 \\
XII & $-0,100$ & 0,137 & $-0,026$ & $-0,138$ & $\mathbf{0 , 6 9 8}$ & $-0,021$ \\
XIII & $-0,022$ & 0,193 & 0,004 & $-0,235$ & $-\mathbf{0 , 5 2 1}$ & 0,284 \\
XIV & 0,194 & 0,126 & 0,351 & 0,016 & $\mathbf{0 , 5 0 0}$ & 0,305 \\
XV & $-0,159$ & 0,156 & 0,052 & $-0,010$ & $-0,128$ & $\mathbf{0 , 7 3 8}$ \\
XVI & 0,154 & $-0,358$ & $-0,427$ & 0,097 & 0,197 & $\mathbf{0 , 5 5 3}$ \\
\hline
\end{tabular}

Sumber: Analisis Data Primer, 2019

Keterangan Indikator:

I : Jarak Fasilitas Ekonomi

II : Jarak Fasilitas Pendidikan

III : Jarak Pusat Kecamatan

IV : Luas Sawah

V : Jumlah Ternak

VI : Jumlah Operator Selluler

VII : Proporsi Penduduk Gizi Buruk

VIII : Jumlah Penduduk Miskin

Data pada Tabel 4 dan didasarkan pada asumsi bahwa pengelompokan variabel ke dalam suatu faktor ditentukan oleh nilai faktor loading, faktor 1 (Faktor Jarak Fasilitas Umum) terdiri dari jarak fasilitas ekonomi, jarak fasilitas pendidikan, jarak pusat kecamatan, faktor 2 (Faktor Sumberdaya Alam) terdiri dari luas sawah, jumlah ternak, jumlah operator, faktor 3 (Kesehatan dan Kemsikinan) terdiri dari proporsi penduduk gizi buruk, jumlah penduduk miskin, jumlah fasilitas kesehatan, faktor 4 (Faktor Mitigasi Bencana) terdiri dari jarak fasilitas kesehatan dan jumlah bencana alam, faktor 5 (Faktor Industri, Pemasaran dan Pengguna Listrik) terdiri dari jumlah industri, proporsi pengguna listrik, jumlah fasilitas ekonomi, faktor 6 (Faktor Proporsi Sekolah dan Proporsi Tenaga Kesehatan) terdiri dari proporsi sekolah dan proporsi tenaga kesehatan. Dengan kata lain, $\begin{array}{ll}\text { IX } & \text { : Jumlah Fasilitas Kesehatan } \\ \text { X } & \text { : Jarak Fasilitas Kesehatan } \\ \text { XI } & \text { : Jumlah Bencana Alam } \\ \text { XII } & \text { : Jumlah Industri } \\ \text { XIII } & \text { : Proporsi Pengguna Listrik } \\ \text { XIV } & \text { : Jumlah Fasilitas Ekonomi } \\ \text { XV } & \text { : Proporsi Sekolah } \\ \text { XVI } & \text { : Proporsi Tenaga Kesehatan }\end{array}$

ketersediaan fasilitas sangat mempengaruhi pembangunan wilayah. Sejalan dengan penelitian ini, ketersediaan fasilitas, khususnya fasilitas sosial berperan krusial dalam mendukung pengembangan wilayah (Sadali, Intizhar, \& Aisyah, 2017).

\section{Pola Spasial Wilayah Tertinggal di Kabupaten Bojonegoro}

Desa-desa tertinggal di Kabupaten Bojonegoro berada pada beberapa topografi dan posisis geografis yang berbeda-beda. Aspek topografi wilayah dan posisi geografis juga dapat menjadi pengaruh atau penyebab ketertinggalan suatu daerah. Pada daerah perbukitan di utara dan selatan Kabupaten Bojonegoro, sebagian besar desa merupakan desadesa yang masuk dalam kategori tertinggal sedangkan pada daerah dataran juga ditemukan desa tertinggal yang 
cukup banyak karena memang luas daerah yang masuk kategori dataran. Apabila dilihat dari segi jarak dengan pusat pertumbuhan, suatu daerah yang berada di pusat kota atau koridor jalan utama akan lebih berkembang dibandingkan daerah yang ada di pinggiran karena kemudahan akses pendidikan, kesehatan, dan ekonomi.

Keragaman posisi geografis inilah yang akan digunakan dalam penelitian ini untuk pengelompokan desa-desa tertinggal. Desa tertinggal di Kabupaten Bojonegoro yang berjumlah 69 desa dalam penelitian ini digolongkan ke dalam beberapa tipologi desa berdasar aspek lingkungan fisik dengan jarak menuju pusat pertumbuhan. Pembagian ini didasarkan pada kondisi kelerengan Kabupaten Bojonegoro yang didominasi oleh kelerengan $0-15 \%$ dan sebagian kecil
15\%-45\%. Menurut Muta'ali (2013) daerah dataran merupakan daerah yang kelerengannya $<15 \%$ dan daerah perbukitan dengan kelerengan 15-40\%. Aspek lingkungan fisik, dalam hal ini kelerengan berhubungan dengan kandungan potensi sumberdaya alam, khususnya pada aspek biotik (flora fauna) dan abiotik (tanah dan air) yang pada akhirnya akan menentukan potensi sumberdaya alam dan tingkat produktivitas desa tersebut. Daerah Kabupaten Bojonegoro kebanyakan bertipologi di dataran dikarenakan memang luas daerah dataran di Kabupaten Bojonegoro memiliki luas kurang lebih $91 \%$ dari luas keseluruhan Kabupaten Bojonegoro. Untuk lebih jelasnya peta pembagian desa berdasar aspek lingkungan fisik dapat dilihat pada Gambar 2.

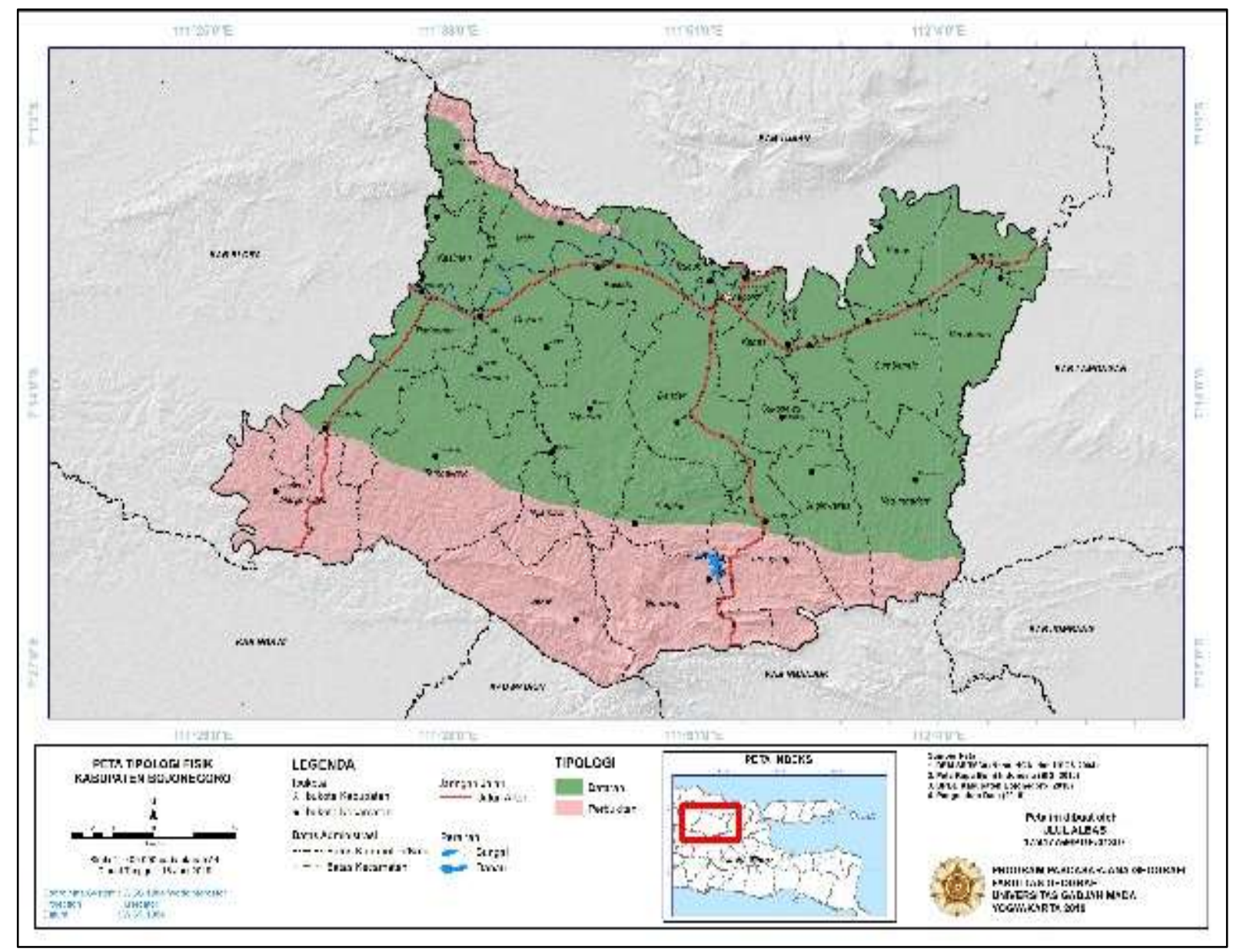

Gambar 2. Peta Tipologi Fisik Kabupaten Bojonegoro 
Aspek jarak menuju pusat pertumbuhan berhubungan dengan kelengkapan fasilitas dan variasi mata pencaharian penduduk selain bertani yang berkaitan dengan penghasilan warga. Aspek jarak juga berhubungan dengan konsep Spread Effect yang menyatakan bahwa perkembangan suatu pusat pertumbuhan akan berpengaruh pada wilayah-wilayah sekitarnya. Semakin jauh suatu daerah dengan pusat pertumbuhan maka efek dari pusat pertumbuhan tersebut akan semakin berkurang dan habis. Aspek jarak menuju pusat pertumbuhan dibagi menjadi lima yaitu desa di kota, desa di pinggiran kota, desa di perdesaan, desa di koridor antar kota, dan desa yang terisolasi.

Tipologi desa di kota merupakan desa yang berciri kekotaan seperti jumlah dan kepadatan penduduk tinggi dan umumnya memiliki fasilitas umum yang lengkap serta terdapat bangunanbangunan pemerintahan. Desa di pinggiran kota merupakan desa yang memiliki aksesibilitas yang baik terhadap kota dan secara sosial ekonomi dipengaruhi oleh kota sehingga jumlah dan kepadatan penduduk desa pinggiran kota juga tinggi. Desa di perdesaan merupakan secara geografis letaknya jauh dari kota dan pengaruhnya dengan ciri-ciri jumlah dan kepadatan penduduk yang rendah serta ketersediaan sarana dan prasarana yang terbatas. Desa di koridor kota merupakan desa yang terletak di sepanjang koridor jalur transportasi darat antara satu kota dengan kota lainnya. Desa koridor kota memiliki kesamaan ciriciri dengan desa di pinggiran kota namun pemicu perkembangannya adalah keberadaan akses transportasi jalan. Desa yang terisolasi merupakan desa yang secara geografis jauh dan tidak memilki aksesibilitas terhadap pusat pertumbuhan. Untuk lebih jelasnya peta pembagian desa berdasar aspek jarak menuju pusat pertumbuhan seperti pada Gambar 3.

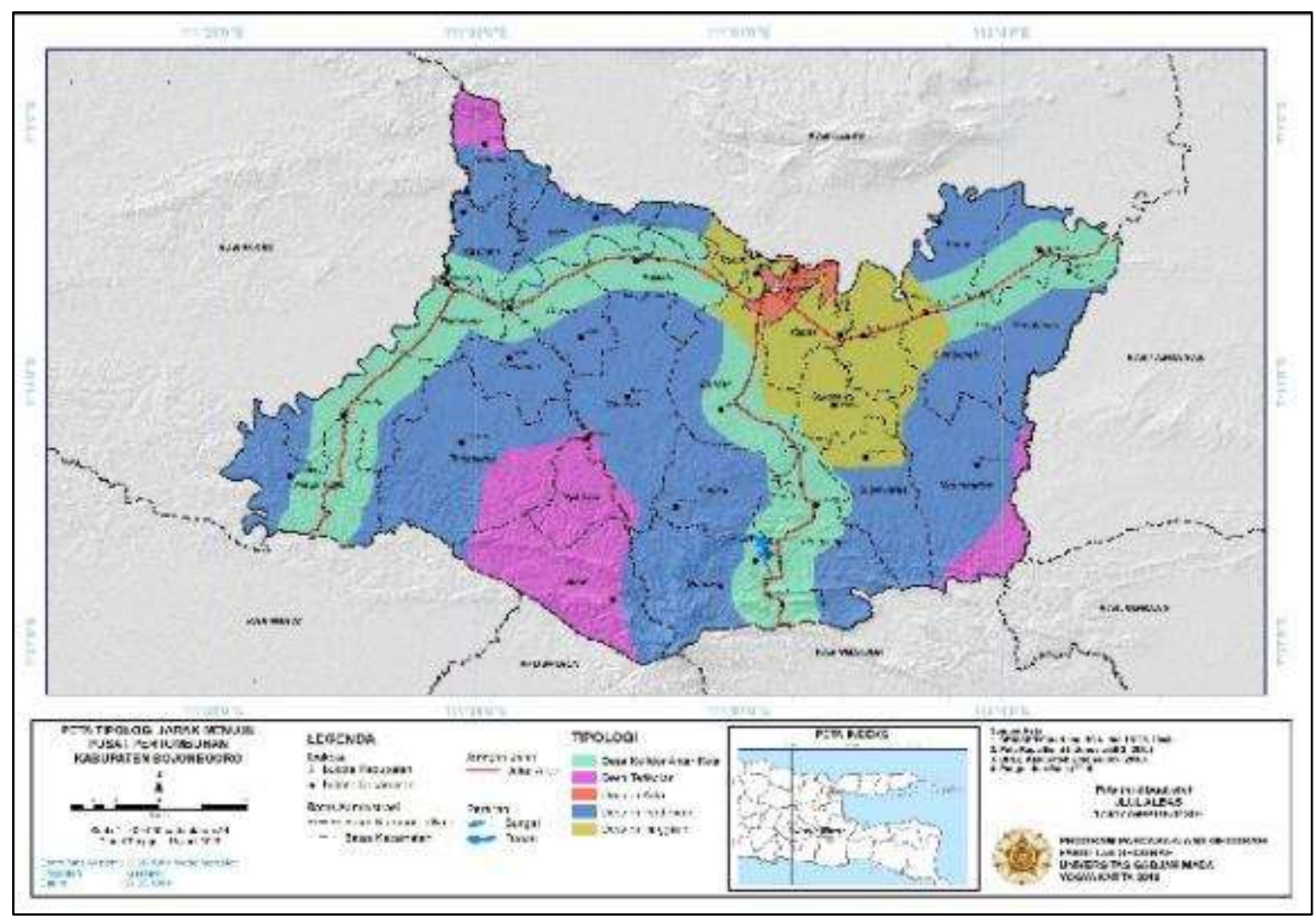

Gambar 4. Peta Tipologi Jarak Menuju Pusat Pertumbuhan 
Dari kedua aspek tersebut, dihasilkan 8 tipologi yang berasal dari penggabungan aspek fisik dan jarak meunuju pusat pertumbuhan. Delapan tipologi tersebut terbagi menjadi 5 tipologi di dataran dan 3 tipologi di perbukitan. Delapan tipologi tersebut antara lain tipologi desa dataran koridor antar kota, desa perbukitan di koridor antar kota, desa dataran di perdesaan, desa perbukitan di perdesaan, desa dataran terisolasi, desa perbukitan terisolasi, dan desa dataran di pinggiran kota.

Tipologi dataran koridor antar kota merupakan tipologi yang terbentuk dari proses overlay desa dataran dengan desa yang berada di koridor antar kota. Koridor antar kota tersebut merupakan jalan arteri penghubung antara Ngawi - Bojonegoro, Blora - Bojonegoro dan Nganjuk Bojonegoro. Sedangkan tipologi perbukitan di koridor antar kota merupakan desa-desa yang juga berada di jalan arteri antar kota. Desa di koridor antar kota ini merupakan desa yang memiliki jarak $3 \mathrm{~km}$ dari jalan arteri dan desa yang berdampingan langsung dengan jalan arteri. Desa di sekitar koridor umumnya cukup maju karena memiliki akses transportasi.

Tipologi dataran perdesaan dan perbukitan perdesaan merupakan tipologi yang terbentuk dari proses overlay desa di dataran atau perbukitan dengan desa bertipe perdesaan. Tipe perdesaan dalam penelitian ini adalah desa yang secara geografis jauh dari kota dan pengaruhnya, namun memiliki hubungan yang baik sehingga memungkinkan hubungan desakota yang mempengaruhi perkembangan keduanya. Desa perdesaan merupakan desa pendukung (hinterland) dari kota didekatnya. Desa ini memilki ciri-ciri kepadatan penduduk yang rendah, sebagian besar bekerja sebagai petani dan ketersediaan sarana cukup terbatas.

Tipologi dataran terisolasi dan perbukitan terisolasi merupakan tipologi yang terbentuk dari proses overlay desa di dataran atau perbukitan dengan desa bertipe terisolasi. Tipe terisolasi dalam penelitian ini adalah desa yang secara geografis berjarak sangat jauh dan tidak memiliki aksesibilitas yang baik terhadap pusat pertumbuhan sehingga tidak terjadi hubungan yang intensif dengan kota. Faktor keterisolasian inilah yang menyebabkan desa tersebut menjadi tertinggal karena sulit dan jauhnya menjangkau fasilitas kesehatan, pendidikan dan ekonomi. Ciri-ciri masyarakat desa terisolasi diantaranya masih cenderung bermatapencaharian sebagai petani, tidak tergantung pada wilayah lain khususnya kota serta ketersediaan infrastruktur sangat terbatas.

Tipologi dataran di pinggiran kota merupakan tipologi yang terbentuk dari proses overlay desa di dataran dengan desa yang berada di pinggiran kota Bojonegoro. Desa pinggiran kota dalam penelitian ini adalah desa-desa yang letaknya relatif dekat dengan kota Bojonegoro atau akses dari kota menuju desa tersebut mudah dan desa disekitar kota dengan jumlah penduduk hanya sekitar 300-480 jiwa yang menjadi petani. Ciri masyarakat desa pinggiran kota ialah jumlah penduduk dan perkembangan permukiman mengalami perkembagan tinggi karena perluasan kota, luas lahan pertanian semakin menyusut, kegiatan non pertanian semakin berkembang sehingga masyarakat menjadi bercampur antara petani dan non-petani. Kajian terkait tentang perkembangan spasial permukiman desa pinggiran kota yang berada dekat dengan kota menunjukkan bahwa perkembangan permukiman di daerah pinggiran kota cenderung berkembang secara leap-frog dan ribbon extension (Bytyqi, 2018; Christiawan, 2019; Jain \& Dimri, 2016). Peta tipologi desa berdasar aspek fisik dan jarak menuju pusat pertumbuhan seperti terlihat pada Gambar 4. 


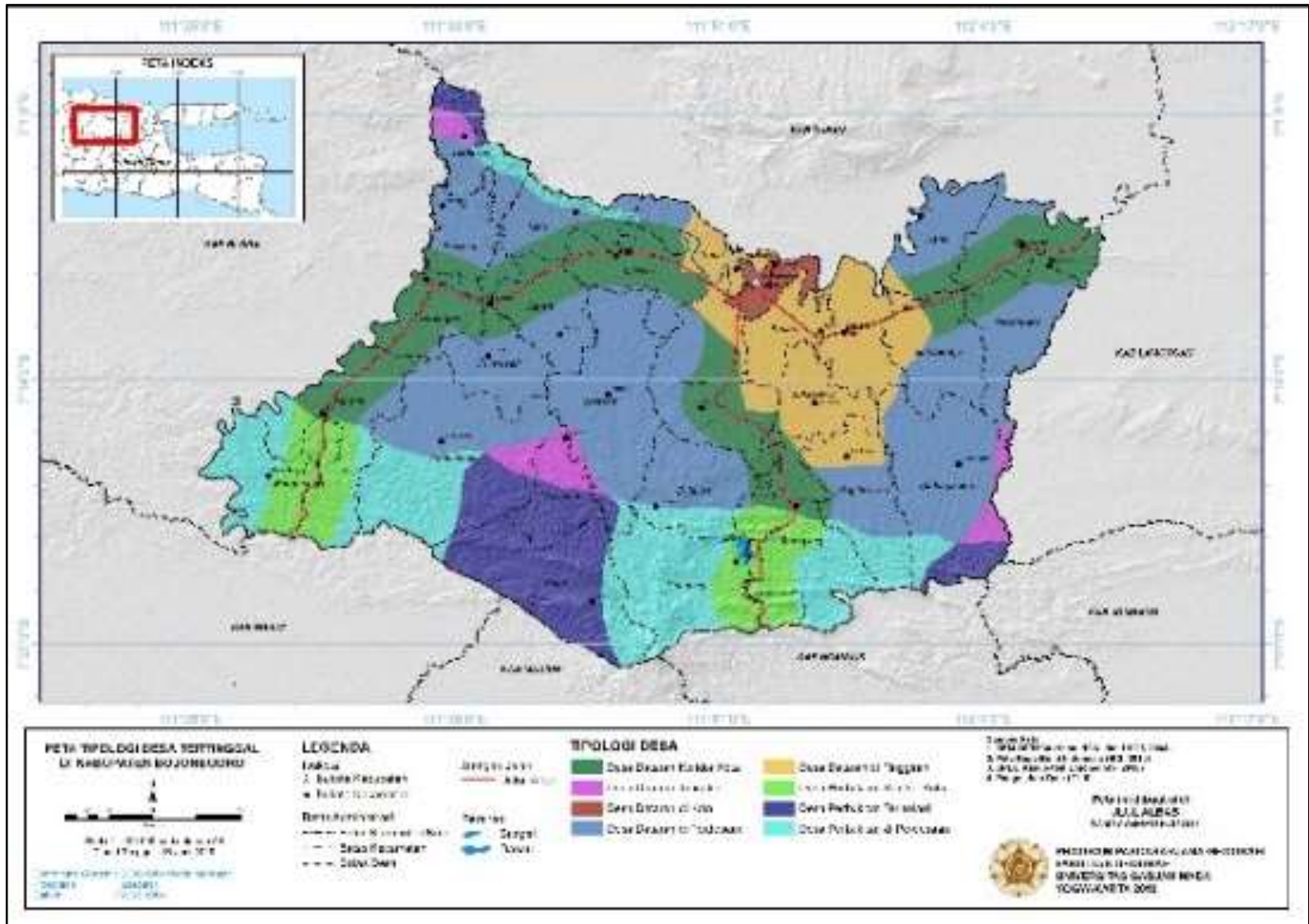

Gambar 4. Peta Tipologi Desa

Setelah terbentuk 8 tipologi, selanjutnya adalah membagi 69 desa yang masuk dalam kategori tertinggal berdasar hasil olah data pada tujuan pertama kedalam 8 tipologi yang sudah terbentuk. Desa tertinggal di dataran koridor antar kota berjumlah 10 desa, desa tertinggal di dataran perdesaan berjumlah 22 desa, desa tertinggal di dataran pinggiran berjumlah 14 desa, desa tertinggal dataran terisolasi hanya 1 desa, desa tertinggal di perbukitan koridor antar kota berjumlah 4 desa, desa tertinggal di perbukitan perdesaan berjumlah 11 desa, dan desa tertinggal di perbukitan terisolasi berjumlah 8 desa, sedangkan desa di dataran kota tidak tidak ada yang masuk dalam kategori tertinggal. Persebaran tertinggal di tiap tipologinya seperti terlihat pada tabel-tabel (5-10) berikut.

Tabel 5. Persebaran Desa Tertinggal Tipologi Dataran Koridor di Kabupaten Bojonegoro

\begin{tabular}{llll}
\hline No & \multicolumn{1}{c}{ Tipologi } & & Desa \\
\hline 1 & Dataran Koridor & Tulungagung & Kalo \\
2 & Dukuh lor & Malo \\
3 & Bonorejo & Gayam \\
4 & Cengungklung & Gayam \\
5 & Sumbang timun & Trucuk \\
6 & Tanggungan & Baureno \\
7 & Kliteh & Malo \\
8 & Tebon & Padangan \\
9 & Ngujung & Temayang \\
10 & Pandantoyo & Temayang \\
\hline Jumlah Desa & 10 & \\
Presentase & $14,49 \%$ & \\
\hline
\end{tabular}


Tabel 6. Persebaran Desa Tertinggal Tipologi Dataran Perdesaan di Kabupaten Bojonegoro

\begin{tabular}{llll}
\hline No & \multicolumn{1}{c}{ Tipologi } & & \multicolumn{1}{c}{ Kecamatan } \\
\hline 1 & Dataran Perdesaan & Kawengan & Kedewan \\
2 & Mlideg & Kedungadem \\
3 & Banaran & Malo \\
4 & Tinumpuk & Purwosari \\
5 & Kacangan & Malo \\
6 & Sendangrejo & Tambakrejo \\
7 & Piyak & Kanor \\
8 & Ngranggon anyar & Kepohbaru \\
9 & Pilang & Kanor \\
10 & Duwel & Kedungadem \\
11 & Pelem & Purwosari \\
12 & Petak & Malo \\
13 & Tlatah & Purwosari \\
14 & Sedahkidul & Purwosari \\
15 & Tlogohaji & Sumberrejo \\
16 & Punggur & Purwosari \\
17 & Simbatan & Kanor \\
18 & Dolokgede & Tambakrejo \\
19 & Sukorejo & Malo \\
20 & Semambung & Kanor \\
21 & Ngrejeng & Purwosari \\
22 & Pucangarum & Baureno \\
\hline Jumlah Desa & 22 & \\
Presentase & 31,88\% & \\
\hline
\end{tabular}

Tabel 7. Persebaran Desa Tertinggal Tipologi Dataran Pinggiran di Kabupaten Bojonegoro

\begin{tabular}{llll}
\hline No & \multicolumn{1}{c}{ Tipologi } & Desa & \multicolumn{1}{c}{ Kecamatan } \\
\hline 1 & Dataran Pinggiran & Bogo & Kapas \\
2 & Semen kidul & Sukosewu \\
3 & Mojo & Kalitidu \\
4 & Sarangan & Kanor \\
5 & Pagerwesi & Trucuk \\
6 & Bakalan & Kapas \\
7 & Cangakan & Kanor \\
8 & Jumput & Sukosewu \\
9 & Kumpul Rejo & Kapas \\
10 & Sranak & Trucuk \\
11 & Pancur & Temayang \\
12 & Mulyorejo & Balen \\
13 & Ngablak & Dander \\
14 & Sekaran & Balen \\
\hline Jumlah Desa & 14 & \\
Presentase & $20,29 \%$ & \\
\hline
\end{tabular}

Tabel 8. Persebaran Desa Tertinggal Tipologi Dataran Terisolasi di Kabupaten Bojonegoro

\begin{tabular}{|c|c|c|c|}
\hline No & Tipologi & Desa & Kecamatan \\
\hline 1 & Dataran Terisolasi & Bondol & Ngambon \\
\hline & h Desa & 1 & \\
\hline Pre & ntase & $1,45 \%$ & \\
\hline
\end{tabular}

Tabel 9. Persebaran Desa Tertinggal Tipologi Perbukitan Koridor di Kabupaten Bojonegoro

\begin{tabular}{llll}
\hline No & \multicolumn{1}{c}{ Tipologi } & & Desa \\
\hline 1 & Perbukitan Koridor & Gondang & Kecamatan \\
2 & Geneng & Margomulyo \\
3 & Kedungsari & Temayang \\
4 & Sugih waras & Ngraho \\
\hline Jumlah Desa & 4 & \\
Presentase & $5,80 \%$ & \\
\hline
\end{tabular}


Tabel 10. Persebaran Desa Tertinggal Tipologi Terisolasi Koridor di Kabupaten Bojonegoro

\begin{tabular}{|c|c|c|c|}
\hline No & Tipologi & Desa & Kecamatan \\
\hline 1 & Perbukitan Terisolasi & Miyono & Sekar \\
\hline 2 & & Karangmangu & Ngambon \\
\hline 3 & & Sekar & Sekar \\
\hline 4 & & Bareng & Sekar \\
\hline 5 & & Deling & Sekar \\
\hline 6 & & Beji & Kedewan \\
\hline 7 & & Bobol & Sekar \\
\hline 8 & & Turi & Tambakrejo \\
\hline Jum & h Desa & 8 & \\
\hline Pres & ntase & $11,60 \%$ & \\
\hline
\end{tabular}

Berdasarkan data pada keenam tabel tersebut, dapat dilihat bahwa sebagian besar desa tertinggal berada di daerah dataran sedangkan desa tertinggal yang masuk pada tipologi terisolasi mayoritas berada pada daerah perbukitan, hal ini terjadi karena topografi yang berbukit dan merupakan daerah yang berbatasan dengan kabupaten lain sehingga pembangunan fasilitas menjadi terkendala dan jarak antara fasilitas cukup jauh seperti desa di Kecamatan Sekar yang 5 desanya masuk dalam kategori tertinggal. Tipologi dataran perdesaan adalah tipologi dengan jumlah desa tertinggal terbanyak yaitu sebanyak 22 desa atau sebesar $31,88 \%$ dari keseluruhan desa tertinggal di Kabupaten Bojonegoro. Banyaknya desa yang masuk dalam tipologi dataran perdesaan karena tipologi dataran perdesaan merupakan tipologi terluas dengan luas $824,52 \mathrm{~km}^{2}$. Tipologi dengan jumlah terbanyak berikutnya adalah tipologi desa dataran di pinggiran dengan jumlah desa sebanyak 14 desa atau 20,29\% dari keseluruhan desa tertinggal di Kabupaten Bojonegoro. Tipologi dengan anggota paling sedikit adalah tipologi desa dataran terisolasi dengan jumlah desa hanya 1 desa atau sebesar $1,45 \%$ dari dari keseluruhan desa tertinggal di Kabupaten Bojonegoro. Jumlah desa yang sedikit ini karena memang luas tipologi dataran terisolasi ini hanya $26,05 \mathrm{~km}^{2}$. Luasan tersebut sangat kecil dibandingkan dengan tipologi perbukitan terisolasi dengan luas $210 \mathrm{~km}^{2}$. Tipologi perbukitan terisolasi memiliki jumlah desa desa tertinggal sebanyak 8 desa atau $11,6 \%$ dari jumlah total desa tertinggal di Kabupaten Bojonegoro. Untuk lebih jelas mengenai persebaran desa tertinggal di Kabupaten Bojonegoro per tipologi dapat dilihat pada Gambar 5.

Peta dalam Gambar 5 menunjukkan bahwa desa tertinggal menyebar di sebalah utara dan selatan Kabupaten Bojonegoro dan menyisakan daerah tengah yang jarang ditemui desa dengan kategori tertinggal. Desa-desa tertinggal di utara Kabupaten Bojonegoro menyebar di sepanjang Bengawan Solo sedangkan desa-desa tertinggal di daerah selatan menyebar di sepanjang perbukitan kapur. Terlihat juga dari gambar 5 bahwa desa-desa tertinggal tersebut letaknya saling berdekatan. Hal ini sesuai dengan penelitian Khalimah (2019) yang meneliti tentang pola spasial kemiskinan khususnya di Pulau Jawa yang menyatakan bahwa memang wilayah tertinggal memiliki pola penyebaran yang berkelompok atau wilayahnya berdekatan serta memiliki karakteristik kemiskinan atau ketertinggalan yang sama. Hal yang sama diungkapkan Tobler dalam Rustiadi, Saefulhakim, \& Panuju (2011) mengenai hukum geografi pertama, yaitu bahwa letak wilayah secara 
geografis akan mempengaruhi kegiatan dan karakteristik sosial wilayah disekitarnya, semakin dekat wilayahnya maka pengaruhnya akan semakin kuat. Daerah perbukitan jika dilihat pada Gambar 5, letaknya berada jauh dari pusat pertumbuhan yang berada di Kecamatan Bojonegoro, sehingga pengaruh kekotaan pusat pertumbuhan sudah tidak lagi ada di daerah perbukitan yang letaknya berada di ujung selatan Kabupaten Bojonegoro.

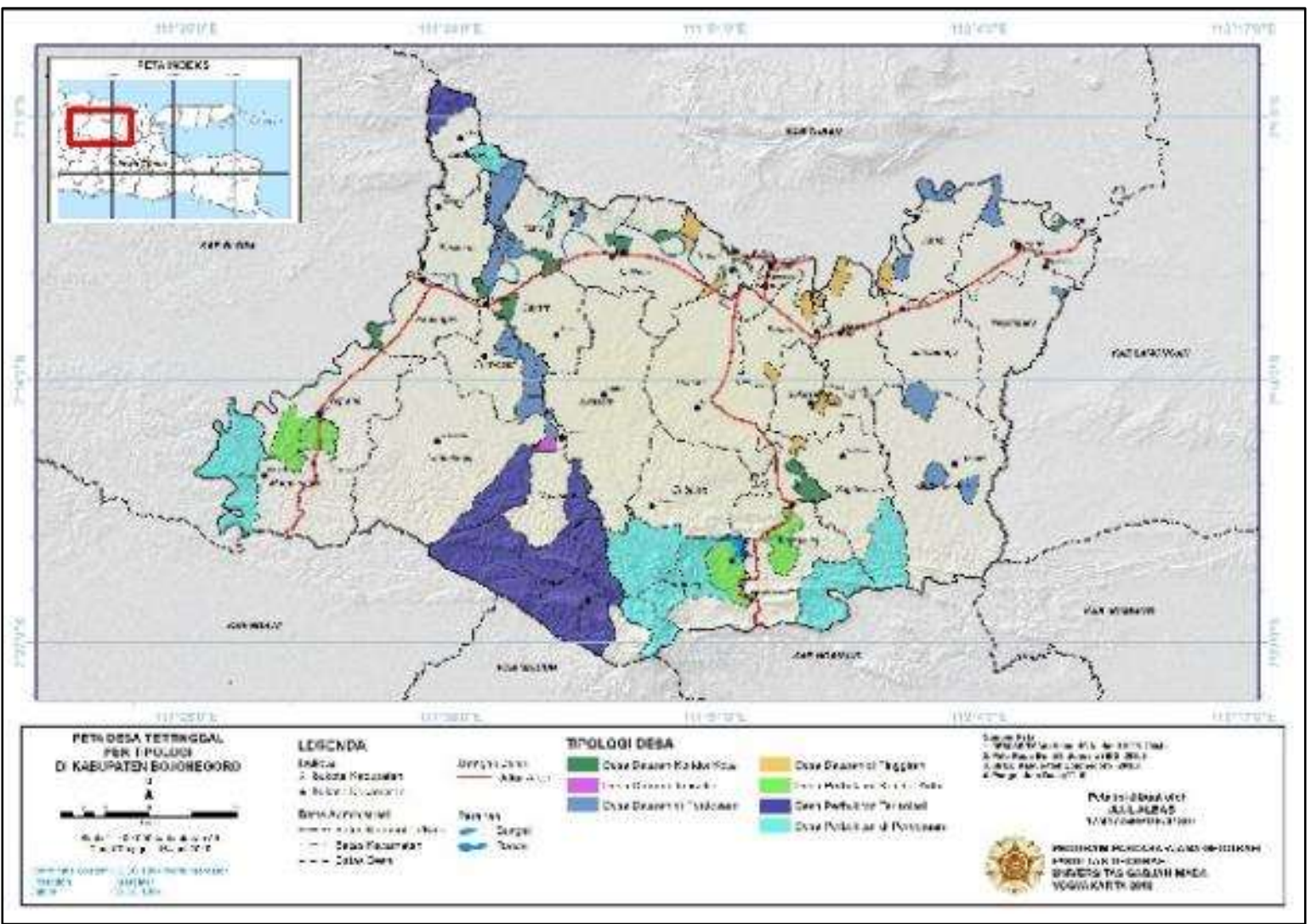

Gambar 8. Peta Desa Tertinggal Per Tipologi Desa

\section{Tipologi Desa Dataran di Koridor Antar Kota}

Tipologi desa dataran di koridor antar kota merupakan tipologi desa yang berada di wilayah dataran yang berada di sekitar jalan penghubung antar kota atau yang bersinggungan langsung dengan jalan penghubung antar kota. Koridor antar kota tersebut merupakan jalan arteri penghubung antara Ngawi - Bojonegoro, Blora - Bojonegoro dan Nganjuk Bojonegoro. Tipologi desa dataran di koridor antar kota beranggotakan 10 desa atau $14,49 \%$ dari total desa tertinggal menurut perhitungan dalam penelitian ini. Tipologi desa dataran di koridor antar kota sebenarnya tidak terlalu tertinggal jika dibandingkan dengan tipologi lain seperti desa yang terisolasi karena terdapat jalan koridor antar kota sebagai faktor pendorong terjadinya pertumbuhan. Faktor penyebab ketertinggalan desa-desa dalam tipologi desa dataran di koridor antar kota di Kabupaten Bojonegoro berdasar perhitungan analisis faktor pada tujuan 1 adalah faktor industri dan pemasaran. Potensi secara geografis yang dekat dengan jalan utama sehingga memudahkan mobilitas warga tidak diimbangi dengan keberadaan industri dan pasar sebagai sarana produksi dan pemasaran produk-produk yang sudah dihasilkan. Kurangnya industri dan pemasaran ini mengakibatkan masyarakat 
belum bisa beralih dari sektor pertanian menjadi sektor industri atau jasa.

\section{Tipologi Desa Dataran di Perdesaan}

Tipologi desa dataran di perdesaan merupakan tipologi desa yang berada di wilayah dataran yang secara geografis jauh dari kota dan pengaruhnya, namun memiliki hubungan atau aksesibilitas yang baik sehingga keduanya saling berpengaruh terhadap perkembangannya. Selain jauh dari kota, bisa juga tipologi desa dataran di perdesaan ini memiliki letak geografis yang jauh dari koridor antar kota namun masih merasakan dampak dari adanya jalan tersebut. Desa ini memiliki ciri-ciri pada umumnya yaitu jumlah dan kepadatan penduduk yang rendah, hubungan sosial yang akrab, sebagian besar penduduk bekerja sebagai petani dan ketersediaan sarana prasarana yang terbatas. Tipologi desa dataran di perdesaan terdiri dari 22 desa atau $31,88 \%$ dari total desa tertinggal menurut perhitungan dalam penelitian ini. Tipologi desa dataran di perdesaan merupakan tipologi dengan jumlah desa terbanyak diantara 7 tipologi yang ada dalam penelitian ini karena tipologi ini merupakan tipologi dengan area terluas dan berada di sekitar Bengawan Solo.

Faktor penyebab ketertinggalan dalam tipologi desa dataran di perdesaan berdasar perhitungan analisis faktor pada tujuan 1 adalah proporsi sekolah dan tenaga kesehatan. Walaupun secara aksesibilitas dan kualitas jalan, desa-desa dalam tipologi desa dataran di perdesaan cukup baik namun ketersediaan sekolah dan tenaga kesehatan dinilai tidak mencukupi.

\section{Tipologi Desa Dataran di Pinggiran Kota}

Tipologi desa dataran di pinggiran kota merupakan tipologi desa yang berada di wilayah dataran yang berada di tepi wilayah pusat pertumbuhan yaitu di tepi
Kecamatan Bojonegoro yang merupakan pusat pertumbuhan di Kabupaten Bojonegoro. Secara geografis desa-desa pada tipologi desa dataran di pinggiran kota memiliki akses yang baik terhadap kota dan secara sosial ekonomi cukup dipengaruhi oleh wilayah pusat. Teori-teori pembangunan daerah telah menetapkan bahwa daerah-daerah yang dekat dengan pusat-pusat ekonomi utama cenderung mendapat manfaat dari efek trickle-down dari pusat-pusat ini. Liao \& Wei (2013) mengemukakan bahwa tipologi desa dataran di pinggiran kota merupakan peralihan antara ciri desa dengan ciri kota. Secara umum desa-desa dalam tipologi ini memiliki ciri jumlah penduduk yang tinggi, luas lahan pertanian yang semakin menyusut serta kegiatan non pertanian semakin berkembang. Tipologi desa dataran di pinggiran kota beranggotakan 14 desa atau 20,29\% dari total desa tertinggal menurut perhitungan dalam penelitian ini.

Faktor penyebab ketertinggalan dalam tipologi desa dataran di pinggiran kota berdasar perhitungan analisis faktor pada tujuan 1 adalah proporsi sekolah dan tenaga kesehatan. Walaupun secara aksesibilitas dan kualitas jalan, desa-desa dalam tipologi desa dataran di pinggiran kota cukup baik namun ketersediaan sekolah dan tenaga kesehatan dinilai tidak mencukupi. Dampaknya adalah rendahnya kualitas sumberdaya manusia pada tipologi desa dataran di pinggiran kota ini seperti yang terlihat pada Desa Semen Kidul yang merupakan desa yang masuk dalam tipologi desa dataran di pinggiran kota. Rendahnya kualitas sumberdaya ini akan mempengaruhi pengembangan daerah karena masyarakat tidak mampu bersaing.

\section{Tipologi Desa Dataran yang Terisolasi}

Tipologi desa dataran yang terisolasi merupakan tipologi desa yang berada di wilayah dataran yang secara 
geografis berjarak sangat jauh dan tidak memiliki aksesibilitas yang baik terhadap pusat-pusat pertumbuhan sehingga tidak memungkinkan adanya hubungan yang intensif dengan kota. Secara umum desa dataran yang terisolasi merupakan desadesa dengan jumlah fasilitas umum yang terbatas serta merupakan daerah jarang dilalui karena tidak ada daya tarik untuk menuju desa dataran yang terisolasi. Secara umum desa-desa dalam tipologi ini memiliki ciri-ciri jumlah dan kepadatan penduduk yang rendah, kegiatan seharihari didominasi dengan bercocok tanam, ketersediaan sarana prasarana yang terbatas. Tipologi desa dataran yang terisolasi beranggotakan 1 desa atau $1,45 \%$ dari total desa tertinggal menurut perhitungan dalam penelitian ini. Tipologi desa dataran yang terisolasi merupakan tipologi dengan jumlah desa tertinggal paling sedikit karena memang wilayahnya juga yang lebih sempit dibanding tipologitipologi yang lain.

Faktor penyebab ketertinggalan dalam tipologi desa dataran yang terisolasi berdasar perhitungan analisis faktor pada tujuan 1 adalah proporsi sekolah dan tenaga kesehatan karena letaknya yang jauh dari pusat pertumbuhan maka ketersediaan sekolah juga terbatas dan menyebar di daerah-daerah lain disekitarnya serta ketersediaan tenaga kesehatan yang kurang karena posisi geografis desa dataran yang terisolasi sehingga mungkin tenaga kesehatan tersebar di beberapa daerah di sekitar desa-desa tipologi desa dataran yang terisolasi tersebut.

\section{Tipologi Desa Perbukitan di Koridor Antar Kota}

Tipologi desa perbukitan di koridor antar kota merupakan tipologi desa yang berada di wilayah perbukitan yang berada di sekitar jalan penghubung antar kota atau yang bersinggungan langsung dengan jalan penghubung antar kota.
Koridor antar kota tersebut merupakan jalan arteri penghubung antara Ngawi Bojonegoro dan Nganjuk - Bojonegoro. Tipologi desa perbukitan di koridor antar kota beranggotakan 4 desa atau 5,8\% dari total desa tertinggal menurut perhitungan dalam penelitian ini.

Tipologi desa perbukitan di koridor antar kota sebenarnya tidak terlalu tertinggal jika dibandingkan dengan tipologi lain seperti desa yang terisolasi karena terdapat jalan koridor antar kota sebagai faktor pendorong terjadinya pertumbuhan. Faktor penyebab ketertinggalan desa-desa dalam tipologi desa dataran di koridor antar kota di Kabupaten Bojonegoro berdasar perhitungan analisis faktor pada tujuan 1 adalah proporsi sekolah dan tenaga kesehatan yang berdampak kualitas sumberdaya manusia di tipologi desa perbukitan di koridor antar kota yang masih rendah yang mengakibatkan terhambatnya perkembangan wilayah tersebut.

\section{Tipologi Desa Perbukitan di Perdesaan}

Tipologi desa perbukitan di perdesaan merupakan tipologi desa yang berada di wilayah perbukitan yang secara geografis jauh dari kota dan pengaruhnya, namun memiliki hubungan atau aksesibilitas yang baik sehingga keduanya saling berpengaruh terhadap perkembangannya. Selain jauh dari kota, bisa juga tipologi desa dataran di perdesaan ini memiliki letak geografis yang jauh dari koridor antar kota namun masih merasakan dampak dari adanya jalan tersebut. Ciri-ciri desa dalam tipologi ini memiliki kemiripan dengan desa-desa pada tipologi desa dataran di perdasaan, namun yang membedakannya adalah kepadatan penduduknya lebih rendah daripada desa-desa pada tipologi desa dataran di perdasaan dan pola permukimannya biasanya menyebar diantara bukit-bukit. Hal ini terjadi karena 
bentuk permukaan bumi yang berbukit mengakibatkan akses menjadi sangat sulit dan warga terkonsentrasi pada dataran di antara bukit-bukit tersebut. Tipologi desa perbukitan di perdesaan terdiri dari 10 desa atau $14,49 \%$ dari total desa tertinggal menurut perhitungan dalam penelitian ini.

Faktor penyebab ketertinggalan dalam tipologi desa perbukitan di perdesaan berdasar perhitungan analisis faktor pada tujuan 1 adalah adalah proporsi sekolah dan tenaga kesehatan yang berdampak kualitas sumberdaya manusia di tipologi desa perbukitan di koridor antar kota yang masih rendah yang mengakibatkan terhambatnya perkembangan wilayah tersebut. Contohnya seperti di Desa Pragelan yang merupakan salah satu desa dari tipologi desa perbukitan di perdesaan yang mengalami kesulitan dalam hal pendidikan karena harus pergi agak jauh dari desanya untuk bersekolah ditambah lagi dengan minimnya tenaga pengajar dan kesehatan di desa tersebut membuat warga tidak mempunyai pilihan lain untuk belajar dan berobat ke luar Desa Pragelan.

\section{Tipologi Desa Perbukitan yang Terisolasi}

Tipologi desa perbukitan yang terisolasi merupakan tipologi desa yang berada di wilayah perbukitan yang secara geografis berjarak sangat jauh dan tidak memiliki aksesibilitas yang baik terhadap pusat-pusat pertumbuhan sehingga tidak memungkinkan adanya hubungan yang intensif dengan kota. Secara umum desa perbukitan yang terisolasi merupakan desa-desa dengan jumlah fasilitas umum yang terbatas serta merupakan daerah jarang dilalui karena tidak ada daya tarik untuk menuju desa dataran yang terisolasi. Ciri-ciri desa dalam tipologi ini memiliki kemiripan dengan desa-desa pada tipologi desa perbukitan yang terisolasi, namun yang membedakannya adalah kepadatan penduduknya lebih rendah daripada desa-desa pada tipologi desa perbukitan yang terisolasi dan pola permukimannya biasanya menyebar diantara bukit-bukit. Tipologi desa perbukitan yang terisolasi beranggotakan 8 desa atau $11,6 \%$ dari total desa tertinggal menurut perhitungan dalam penelitian ini.

Faktor penyebab ketertinggalan dalam tipologi desa perbukitan yang terisolasi berdasar perhitungan analisis faktor pada tujuan 1 adalah faktor mitigasi bencana. Akses menuju fasilitas umum terutama fasilitas kesehatan yang lengkap seperti yang berada di pusat pertumbuhan mengakibatkan proses mitigasi bencana berjalan kurang maksimal. Padahal saat terjadi bencana seperti banjir bandang memerlukan penanganan yang cepat dan tepat untuk meminimalisir korban.

Secara umum faktor yang menjadi penyebab ketertinggalan di beberapa tipologi adalah proporsi sekolah dan tenaga kesehatan kecuali tipologi desa dataran di koridor antar kota dengan faktor yang menjadi penyebab ketertinggalan adalah faktor industri dan pemasaran serta tipologi desa perbukitan yang terisolasi dengan faktor yang menjadi penyebab ketertinggalan adalah faktor mitigasi bencana. Hal ini menandakan bahwa pentingnya peningkatan kualitas sumberdaya manusia dengan pendidikan dan pelayanan kesehatan yang merata di setiap sudut Kabupaten Bojonegoro agar masyarakat Kabupaten Bojonegoro memiliki daya saing.

\section{Kesimpulan}

Dari hasil penelitian ini dapat diketahui bahwa tingkat perkembangan wilayah desa-desa di Kabupaten Bojonegoro di dominasi oleh desa dengan kategori berkembang dengan presentase $63,72 \%$ dan hanya $16,05 \%$ desa dengan kategori tertinggal. Desa dengan kategori tertinggal umumnya berada pada daerah 
perbukitan dan di sekitar Bengawan Solo. Tingkat perkembangan wilayah desa di Kabupaten Bojonegoro dibentuk oleh faktor jarak fasilitas umum, faktor sumberdaya alam, faktor kesehatan dan kemiskinan, faktor mitigasi bencana, faktor industri, pemasaran, pengguna listrik dan faktor proporsi sekolah, proporsi tenaga kesehatan. Desa tertinggal di Kabupaten Bojonegoro dibagi kedalam 8 tipologi meliputi desa dataran di kota, desa dataran di koridor antar kota, desa dataran di perdesaan, desa dataran di pinggiran kota, desa dataran yang terisolasi, desa perbukitan di koridor antar kota, desa perbukitan di perdesaan, desa perbukitan yang terisolasi. Desa tertinggal paling banyak berada pada tipologi desa dataran di perdesaan karena tipologi ini merupakan tipologi dengan area terluas dan berada di sekitar Bengawan Solo sedangkan untuk tipologi desa dataran di kota tidak terdapat desa tertinggal sama sekali. Desa-desa tertinggal pada tipologi desa dataran di perdesaan, desa dataran di pinggiran kota, desa dataran yang terisolasi, desa perbukitan di koridor antar kota, dan desa perbukitan di perdesaan di sebabkan oleh faktor proporsi sekolah dan tenaga kesehatan, desa-desa tertinggal pada tipologi dataran di koridor antar kota disebabkan oleh faktor industri dan pemasaran, sedangkan desa-desa tertinggal pada tipologi desa perbukitan yang terisolasi disebabkan oleh faktor mitigasi bencana.

\section{Daftar Pustaka}

Ardiyanto. (2018). Ketimpangan Pembangunan Dan Arahan Rencana Pengembangan Wilayah Kota Palembang. Institut Pertanian Bogor.

Bhattacharyya, S., \& Resosudarmo, B. P. (2014). Growth, Growth Accelerations, and the Poor: Lessons from Indonesia. UK and Australia: World Development.

Bytyqi, V. (2018). The Impacts of Settlement Extension on Soil
Resources: A Case Study in Drenica River Basin ( Kosovo ). Media Komunikasi Geografi, 19(1), 101113.

Chen, K., \& Ge, Y. (2015). Spatial Point Pattern Analysis on The Villages in China's Poverty-Stricken Areas. Journal Environmental Sciences, 27, 98-105.

Christiawan, P. I. (2019). Tipe Urban Sprawl dan Eksistensi Pertanian di Wilayah Pinggiran Kota Denpasar. Jurnal Wilayah Dan Lingkungan, 7(2).

Jain, M., \& Dimri, A. P. (2016). Urban sprawl Patterns and Processes in Delhi from 1977 to 2014 Based on Remote Sensing and Spatial Metrics Approaches. Earth Interactions Journal, 2, 1-29.

Khalimah, N. I. (2019). Analisis Pola Spasial Kemiskinan di Pulau Jawa. Universitas Gadjah Mada.

Liao, H. F., \& Wei, Y. H. D. (2013). Tncs' Technology Linkages with Domestic Firms: An Investigation of The Ict Industry in Suzhou, China. Environment and Planning, 31, 460473.

Muta'ali, L. (2011). Kapita Selekta Pengembangan Wilayah. Yogyakarta: Badan Penerbit Fakultas Geografi (BPFG) UGM.

Muta'ali, L. (2013). Pengembangan Wilayah Perdesaan. Yogyakarta: Badan Penerbit Fakultas Geografi (BPFG) UGM.

Muta'ali, L. (2014). Pengembangan Wilayah Tertinggal. Yogyakarta: Badan Penerbit Fakultas Geografi (BPFG) UGM.

Muta'ali, L. (2015). Teknik Analisis Regional Untuk Perencanaan Wilayah, Tata Ruang dan Lingkungan. Yogyakarta: Badan Penerbit Fakultas Geografi Universitas Gadjah Mada.

Rustiadi, E., Saefulhakim, S., \& Panuju, D. R. (2011). Perencanaan Dan Pengembangan Wilayah. Jakarta: Crestpent Press.

Sadali, M. I., Intizhar, F., \& Aisyah. (2017). Analisis Ketersediaan Fasilitas Sosial di Kabupaten Banjarnegara, sebagai Pendukung Kondisi Darurat Bencana dan Pengembangan Wilayah. Media 
Pengembangan Sentra Industri Kecamatan Tempuran Berdasarkan Indeks Spesialisasi dan Konsentrasi Spasial di Kabupaten Magelang/ Andi Panca Putra, Andri Kurniawan, Sri Rahayu Budiani

Komunikasi Geografi, 18(2), 128145.

Sugiyarto, Mulyo, J. H., \& Seleky, R. N.

(2015). Kemiskinan Dan

Ketimpangan Pendapatan Rumah

Tangga Di Kabupaten Bojonegoro.

Jurnal Agro Ekonomi, 26(2), 115120. 